\title{
Meso-substituted Corroles from Nitrosoalkenes and Dipyrromethanes
}

\author{
Susana M. M. Lopes and Teresa M. V. D. Pinho e Melo* \\ CQC and Department of Chemistry, University of Coimbra, 3004-535 Coimbra, Portugal \\ *Email: tmelo@ci.uc.pt
}

\section{Supporting Information}

Table of contents

1. Copies of ${ }^{1} \mathrm{H}$ and ${ }^{13} \mathrm{C}$ NMR spectra of new bilanes and hexapyrroles..................S2

2. Copies of ${ }^{1} \mathrm{H}$ NMR, ${ }^{13} \mathrm{C}$ NMR and UV-Vis spectra of new corroles..........................S12

3. Copies of ${ }^{1} \mathrm{H}$ NMR and UV-Vis spectra of new porphyrins.........................S20 


\section{Copies of ${ }^{1} \mathrm{H}$ and ${ }^{13} \mathrm{C}$ NMR spectra of new bilanes and hexapyrroles}
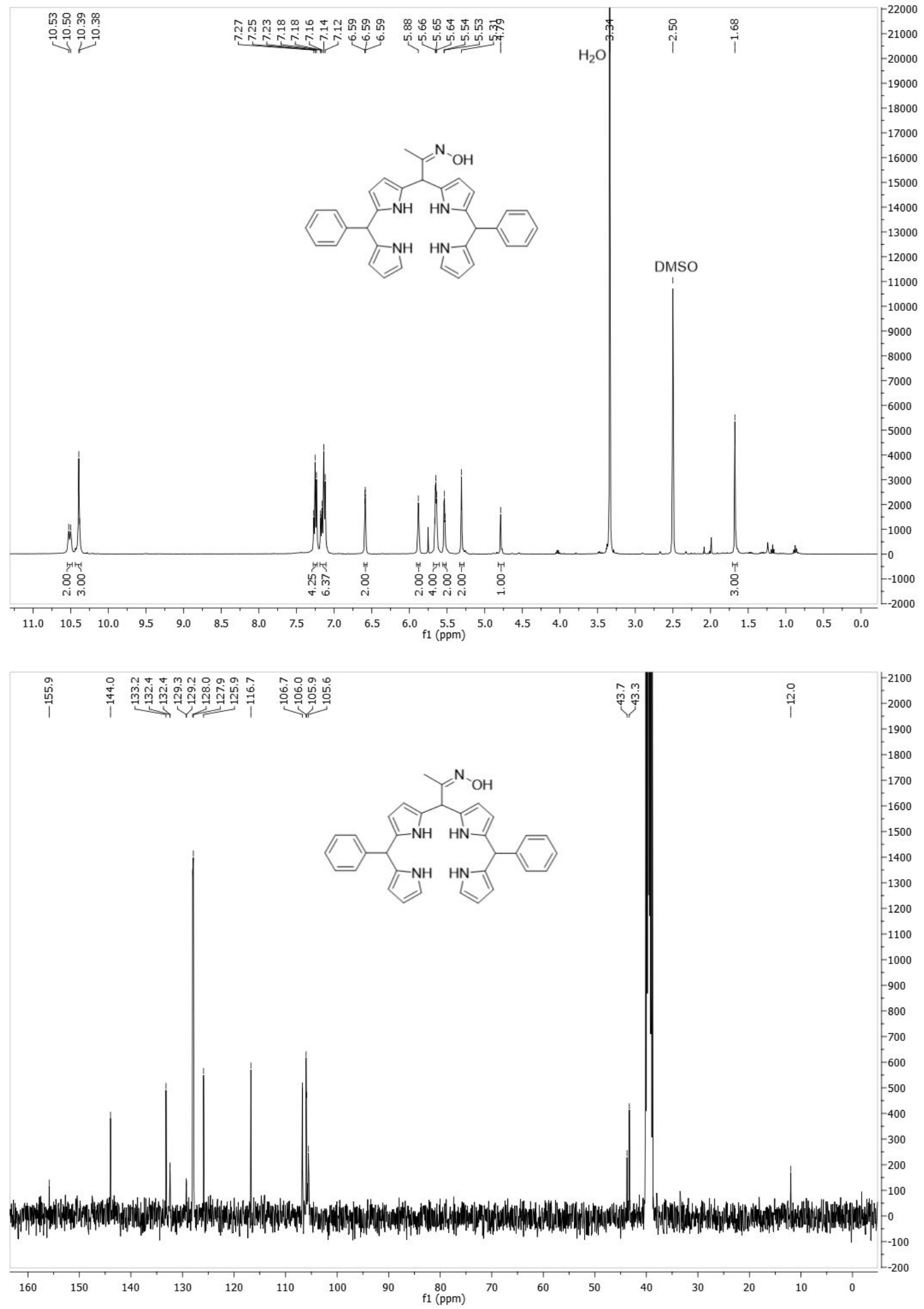

Figure S1. ${ }^{1} \mathrm{H}$ and ${ }^{13} \mathrm{C}$ NMR spectra $\left(\mathrm{DMSO}-d_{6}\right)$ of bilane 3a, from the reaction carried out using the $\mathrm{H}_{2} \mathrm{O} / \mathrm{CH}_{2} \mathrm{Cl}_{2}$ solvent system (see Table 1, Entry 4). 

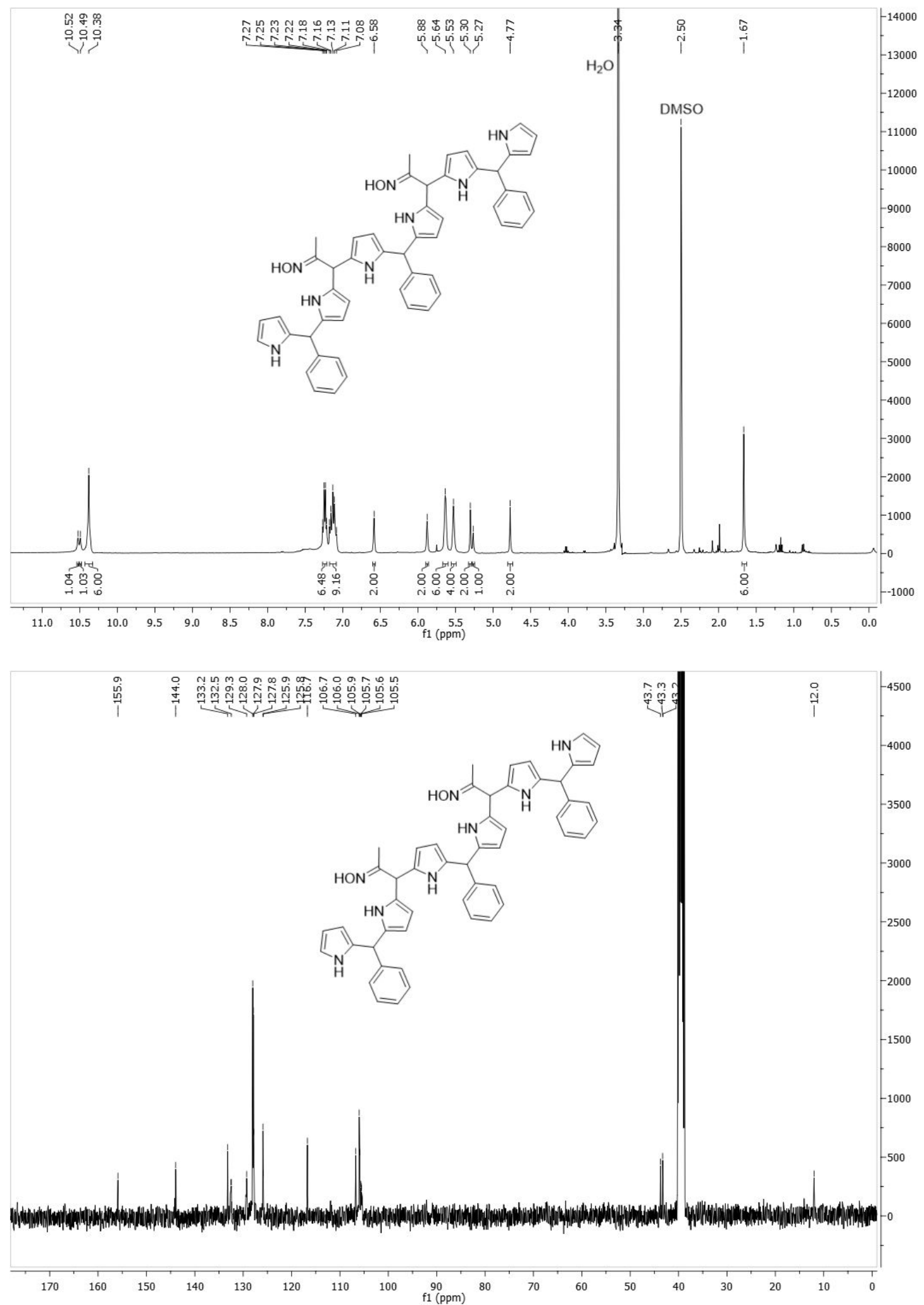

Figure S2. ${ }^{1} \mathrm{H}$ and ${ }^{13} \mathrm{C}$ NMR spectra $\left(\mathrm{DMSO}-d_{6}\right)$ of hexapyrrole 4a, from the reaction carried out using the $\mathrm{H}_{2} \mathrm{O} / \mathrm{CH}_{2} \mathrm{Cl}_{2}$ solvent system (see Table 1, Entry 4). 

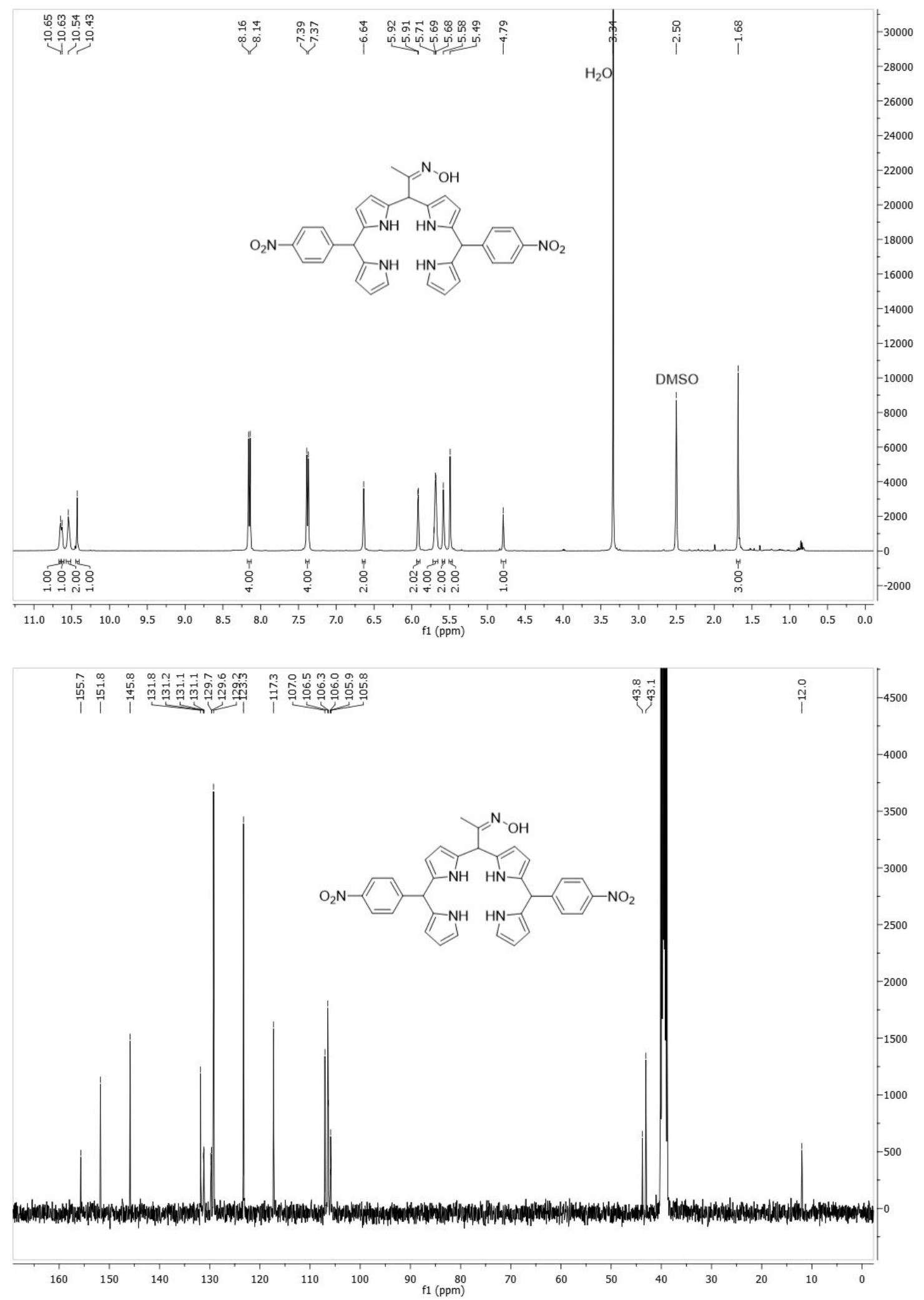

Figure S3. ${ }^{1} \mathrm{H}$ and ${ }^{13} \mathrm{C}$ NMR spectra (DMSO- $d_{6}$ ) of bilane $\mathbf{3 b}$, from the reaction carried out using the $\mathrm{H}_{2} \mathrm{O} /$ EtOAc solvent system (see Table 1, Entry 6). 


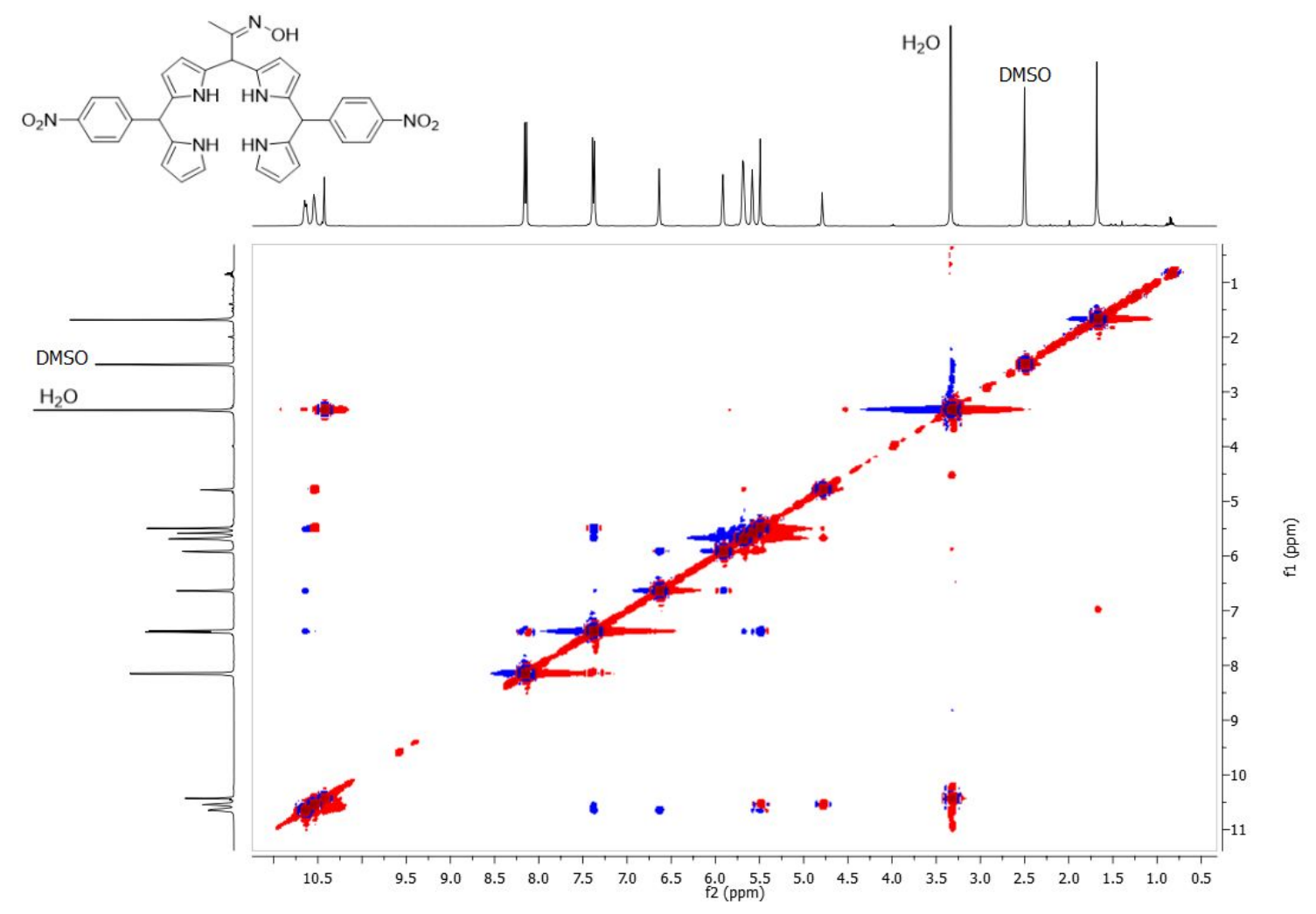

Figure S4. NOESY spectrum (DMSO- $d_{6}$ ) of bilane $\mathbf{3 b}$, from the reaction carried out using the $\mathrm{H}_{2} \mathrm{O} /$ EtOAc solvent system (see Table 1, Entry 6). 

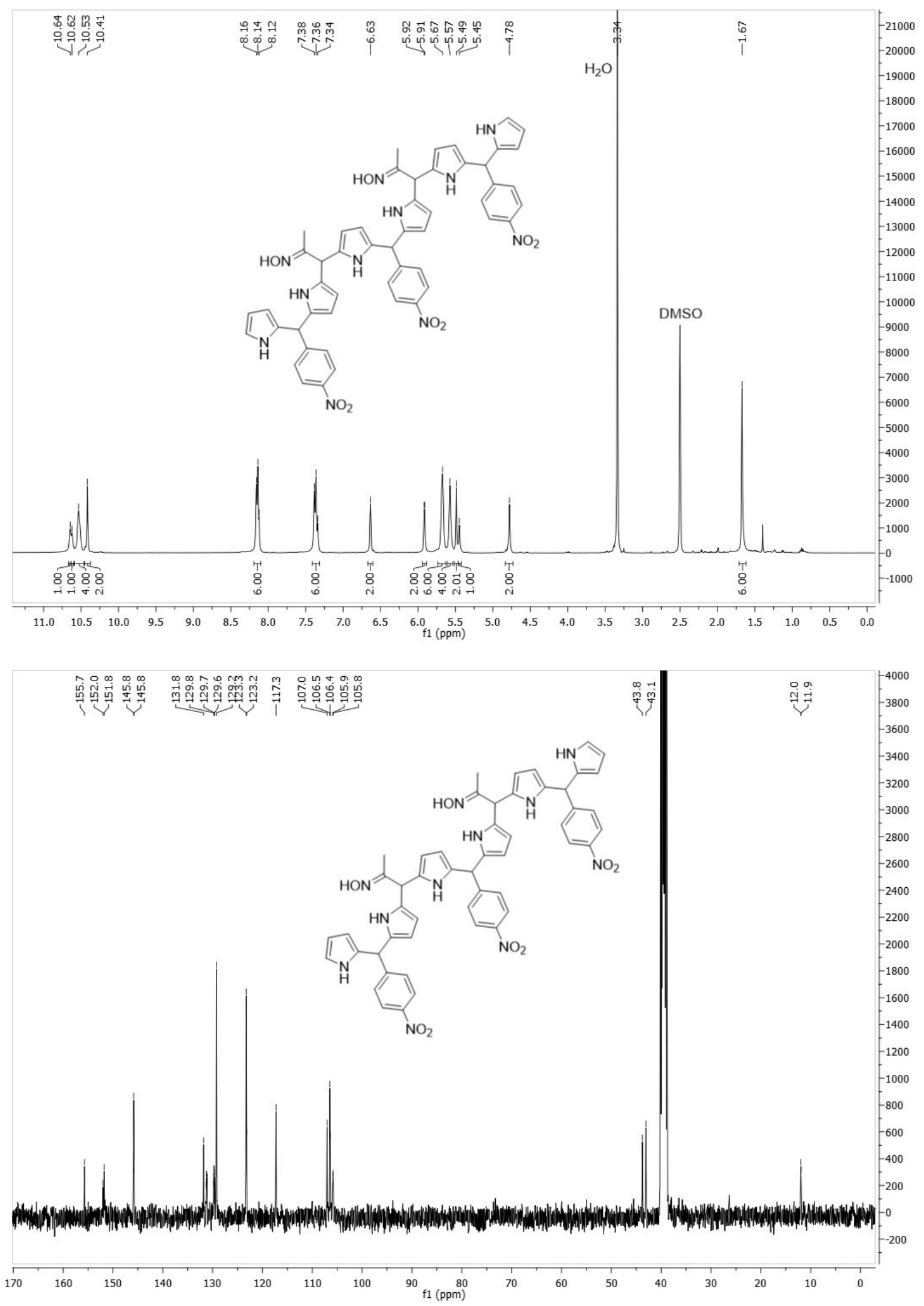

Figure S5. ${ }^{1} \mathrm{H}$ and ${ }^{13} \mathrm{C}$ NMR spectra (DMSO- $d_{6}$ ) of hexapyrrole $\mathbf{4 b}$, from the reaction carried out using the $\mathrm{H}_{2} \mathrm{O} /$ EtOAc solvent system (see Table 1, Entry 6). 

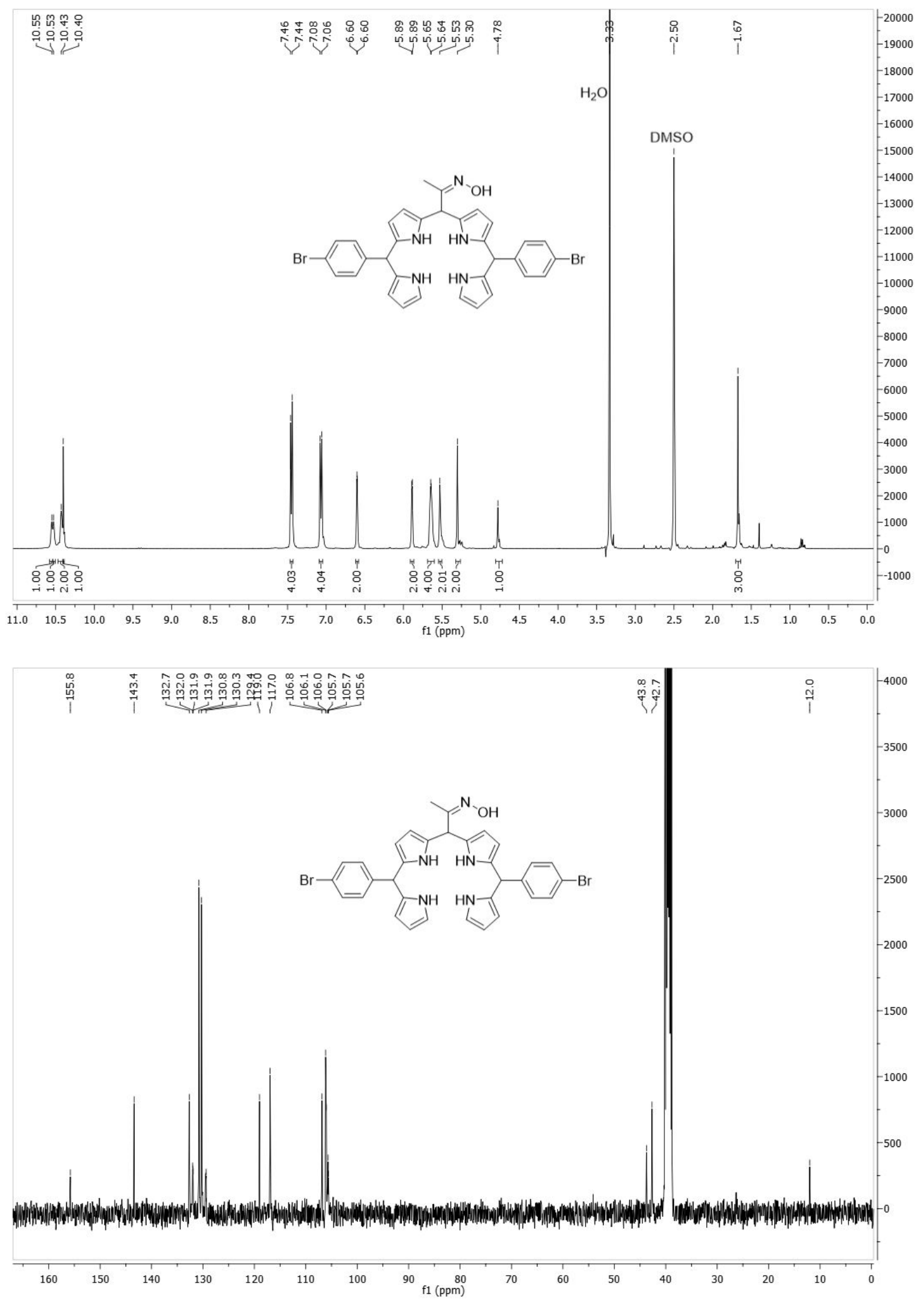

Figure S6. ${ }^{1} \mathrm{H}$ and ${ }^{13} \mathrm{C}$ NMR spectra $\left(\mathrm{DMSO}-d_{6}\right)$ of bilane $\mathbf{3 c}$, from the reaction carried out using the $\mathrm{H}_{2} \mathrm{O} / \mathrm{CH}_{2} \mathrm{Cl}_{2}$ solvent system (see Table 1, Entry 8). 

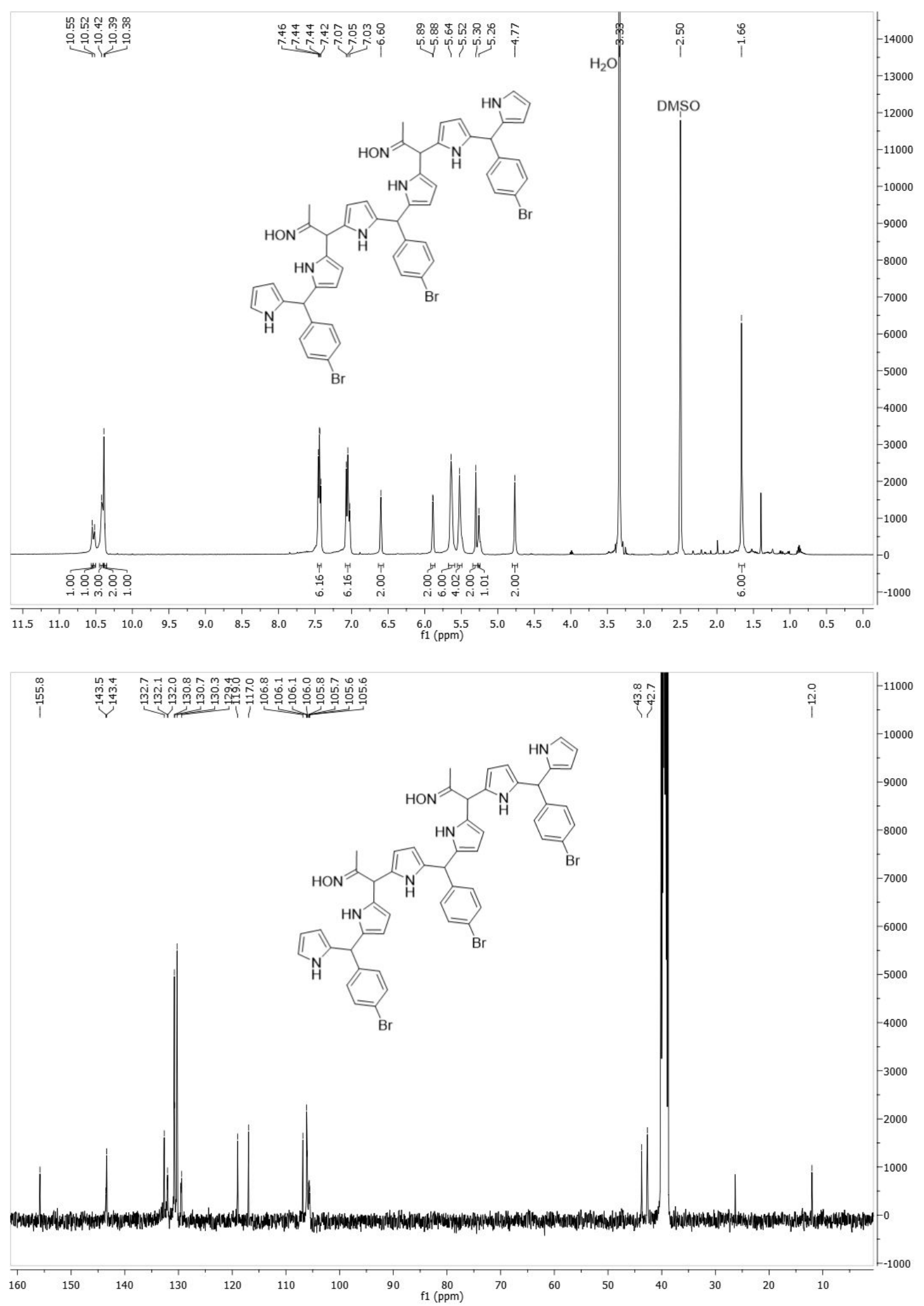

Figure S7. ${ }^{1} \mathrm{H}$ and ${ }^{13} \mathrm{C}$ NMR spectra $\left(\mathrm{DMSO}-d_{6}\right)$ of hexapyrrole $4 \mathbf{c}$, from the reaction carried out using the $\mathrm{H}_{2} \mathrm{O} / \mathrm{CH}_{2} \mathrm{Cl}_{2}$ solvent system (see Table 1, Entry 8). 

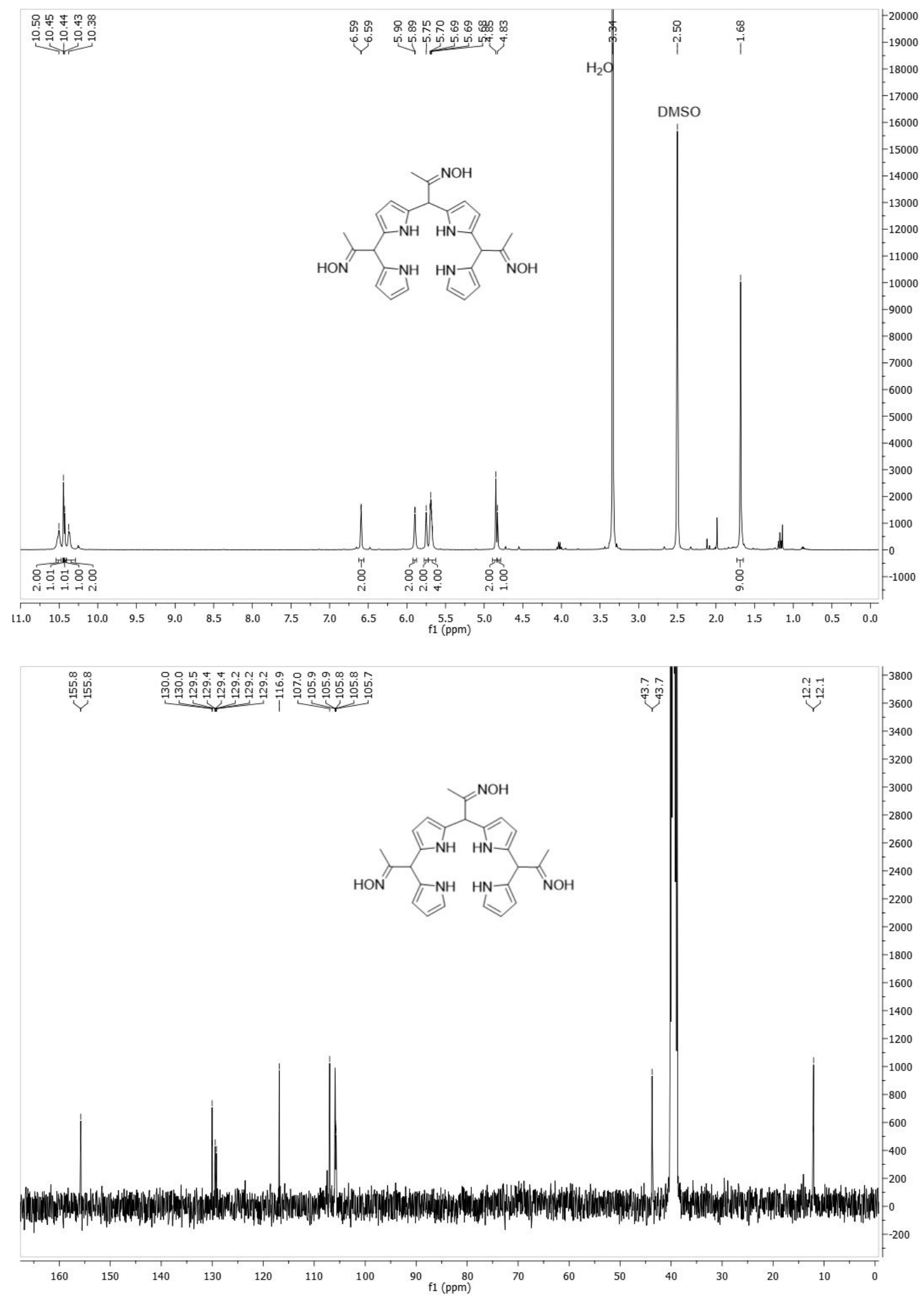

Figure S8. ${ }^{1} \mathrm{H}$ and ${ }^{13} \mathrm{C}$ NMR spectra (DMSO- $d_{6}$ ) of bilane 3d, from the reaction carried out using the $\mathrm{H}_{2} \mathrm{O} /$ EtOAc solvent system (see Scheme 2). 

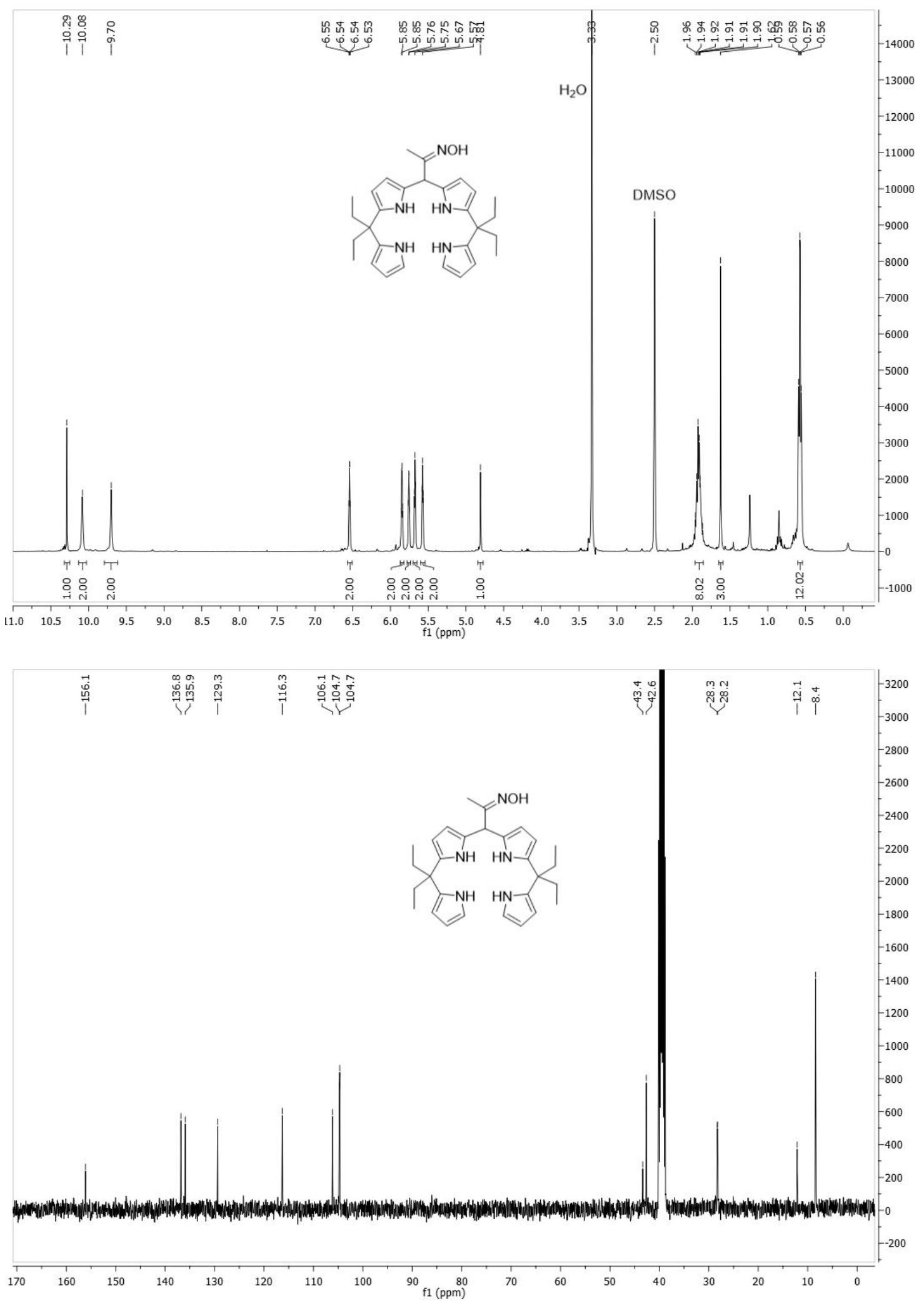

Figure S9. ${ }^{1} \mathrm{H}$ and ${ }^{13} \mathrm{C}$ NMR spectra $\left(\mathrm{DMSO}-d_{6}\right)$ of bilane $\mathbf{3 e}$, from the reaction carried out using the $\mathrm{H}_{2} \mathrm{O} / \mathrm{CH}_{2} \mathrm{Cl}_{2}$ solvent system (see Scheme 2). 



Figure S10. ${ }^{1} \mathrm{H}$ and ${ }^{13} \mathrm{C}$ NMR spectra (DMSO- $d_{6}$ ) of the mixture $E: Z$ of bilanes 7, from the reaction carried out using the $\mathrm{H}_{2} \mathrm{O} / \mathrm{CH}_{2} \mathrm{Cl}_{2}$ solvent system (see Scheme 3). 
2. Copies of ${ }^{1} \mathrm{H}$ NMR, ${ }^{13} \mathrm{C}$ NMR and UV-Vis spectra of new corroles
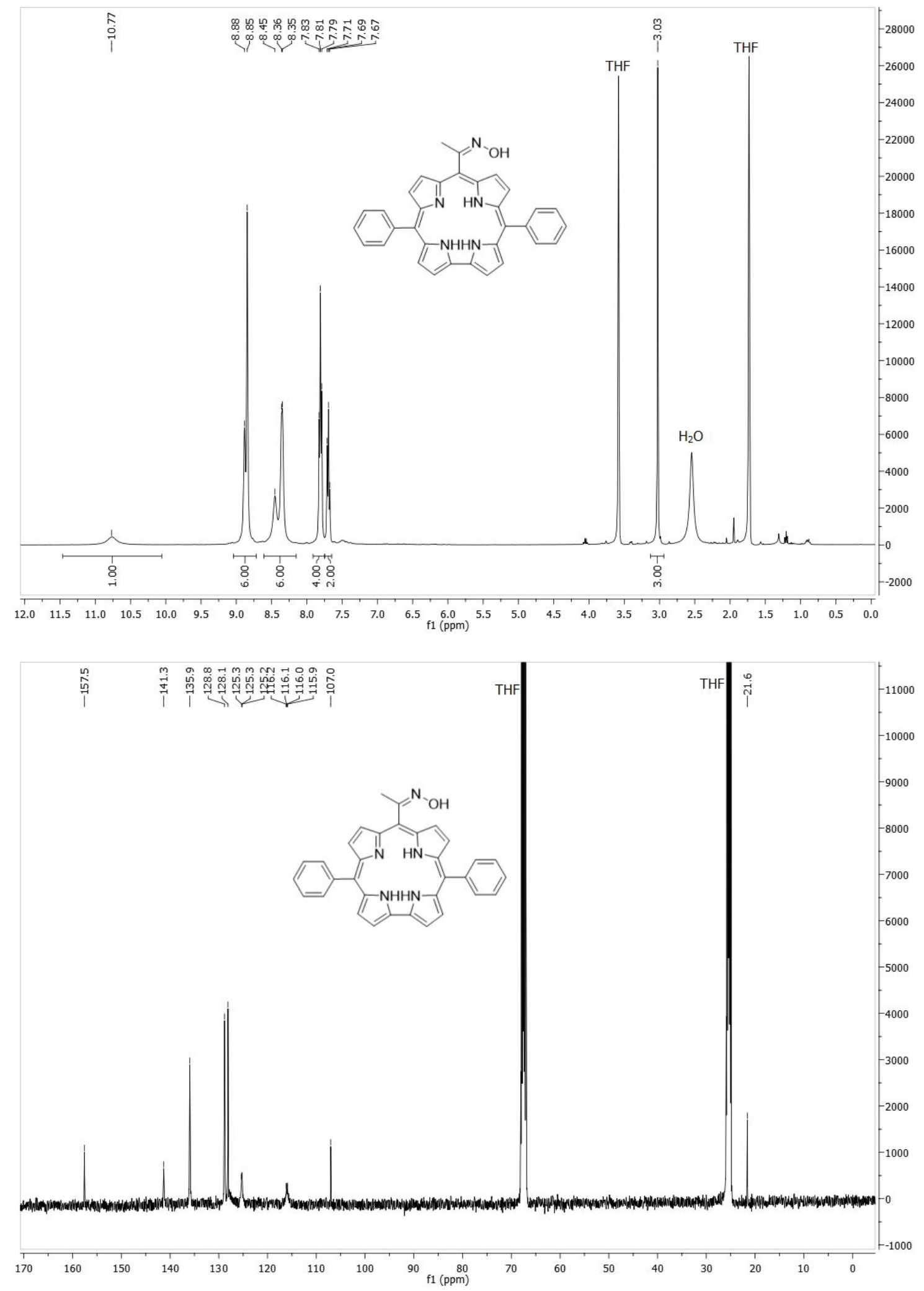

Figure S11. ${ }^{1} \mathrm{H}$ NMR and ${ }^{13} \mathrm{C}$ NMR spectra (THF- $\left.d_{8}\right)$ of corrole 5a, from the reaction carried out using THF as solvent (see Table 2, Entry 5). 


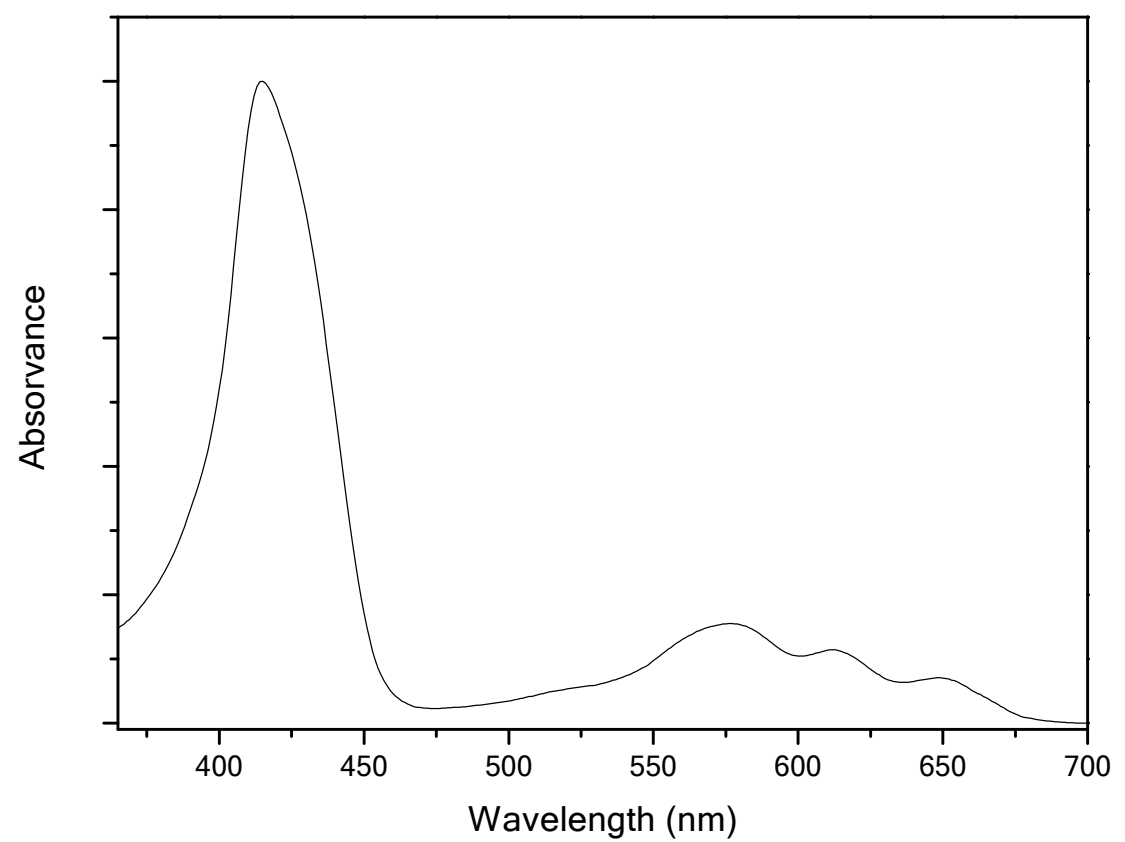

Figure S12. UV-Vis spectrum of corrole 5a (THF). 

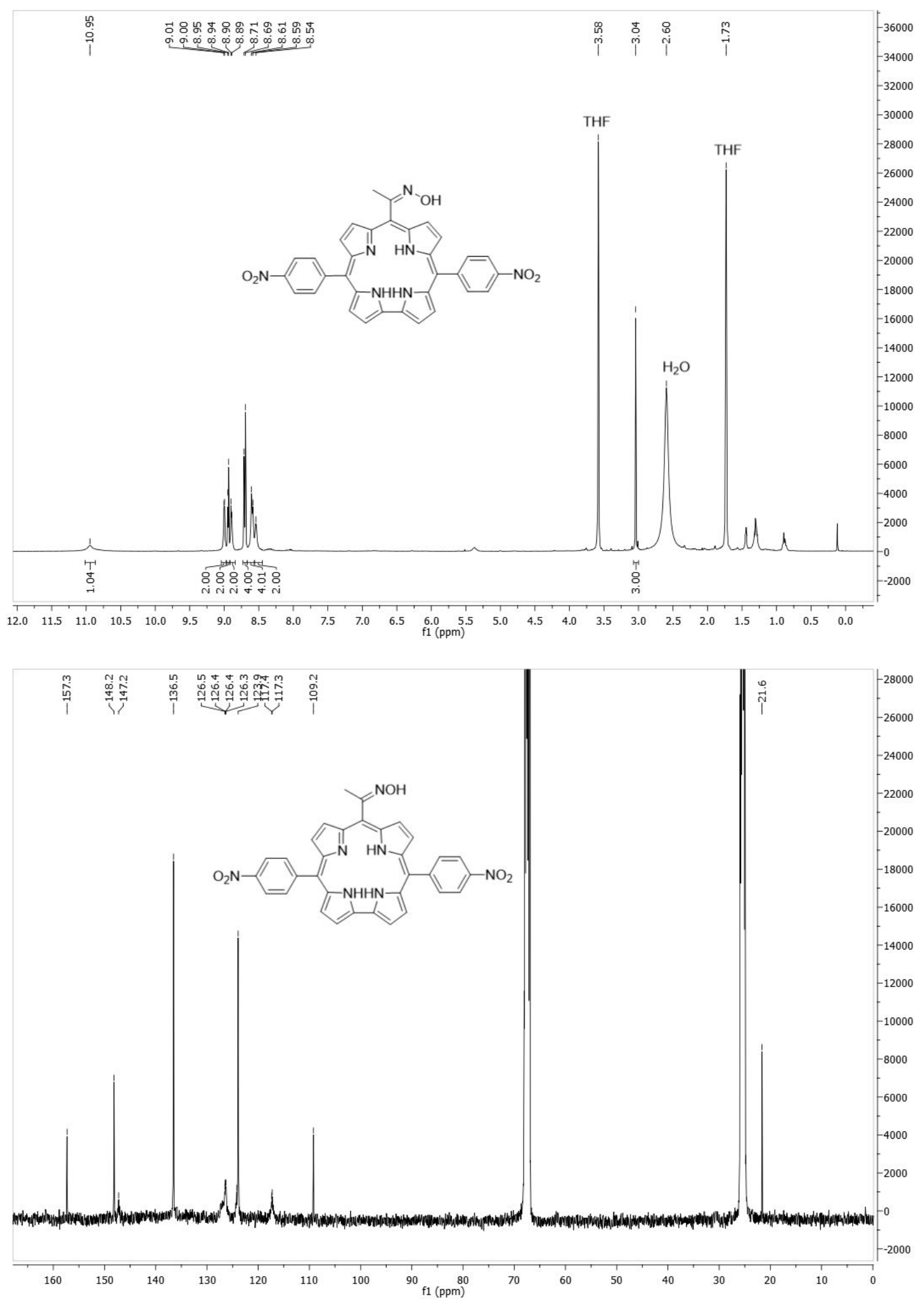

Figure S13. ${ }^{1} \mathrm{H}$ NMR and ${ }^{13} \mathrm{C}$ NMR spectra of corrole $\mathbf{5 b}\left(\mathrm{THF}-d_{8}\right)$. 


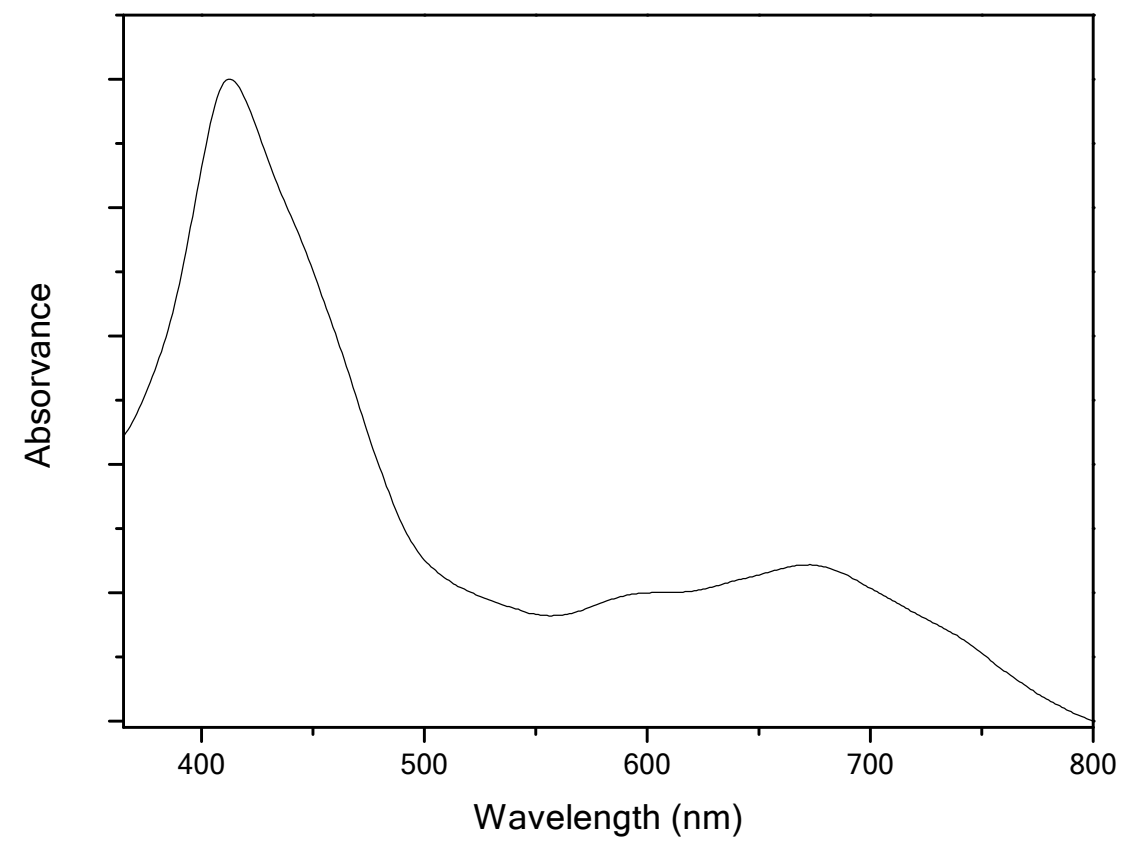

Figure S14. UV-Vis spectrum of corrole $\mathbf{5 b}(\mathrm{THF}, \mathrm{pH}=8)$. 

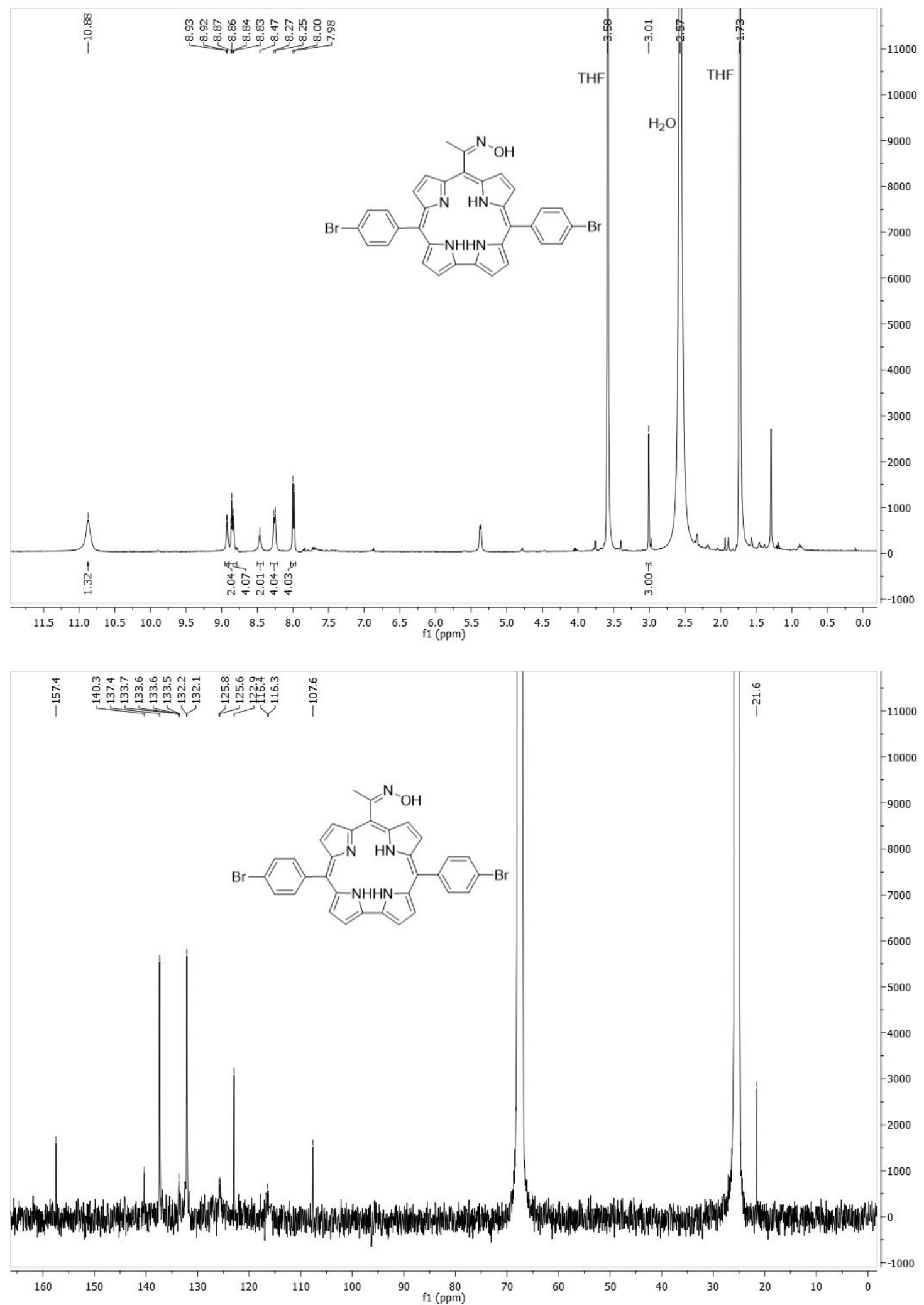

Figure S15. ${ }^{1} \mathrm{H}$ NMR and ${ }^{13} \mathrm{C}$ NMR spectra of corrole 5c (THF- $\left.d_{8}\right)$. 


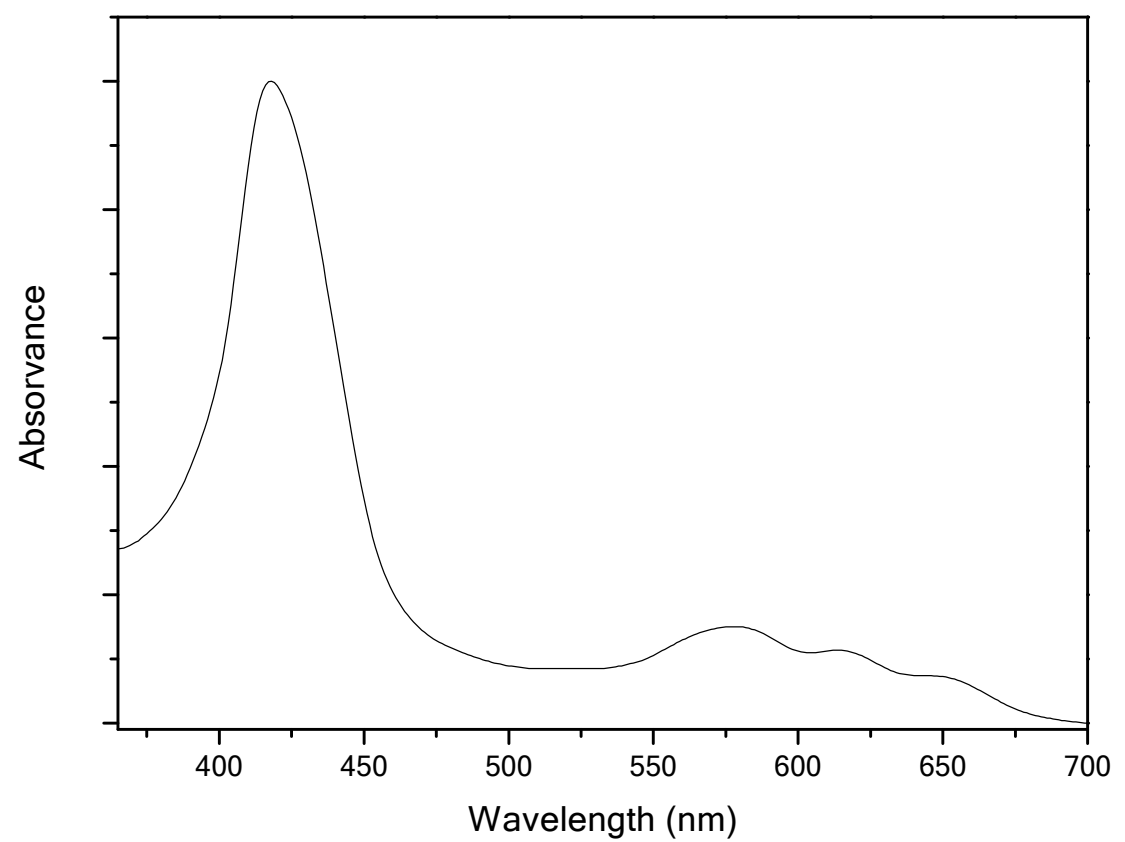

Figure S16. UV-Vis spectrum of corrole $\mathbf{5 c}$ (THF). 

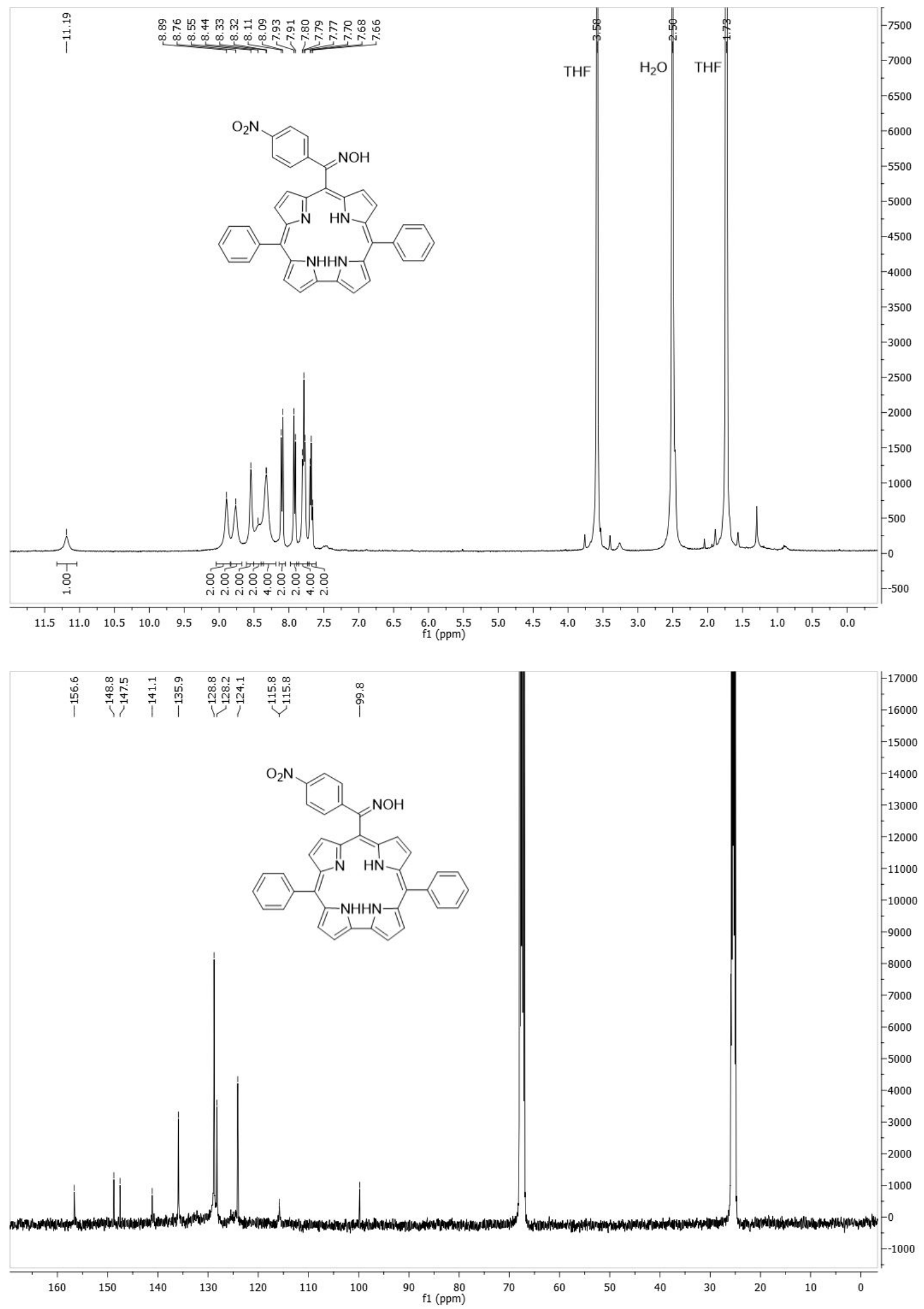

Figure S17. ${ }^{1} \mathrm{H}$ NMR and ${ }^{13} \mathrm{C}$ NMR spectra of corrole 8 (THF- $d_{8}$ ). 


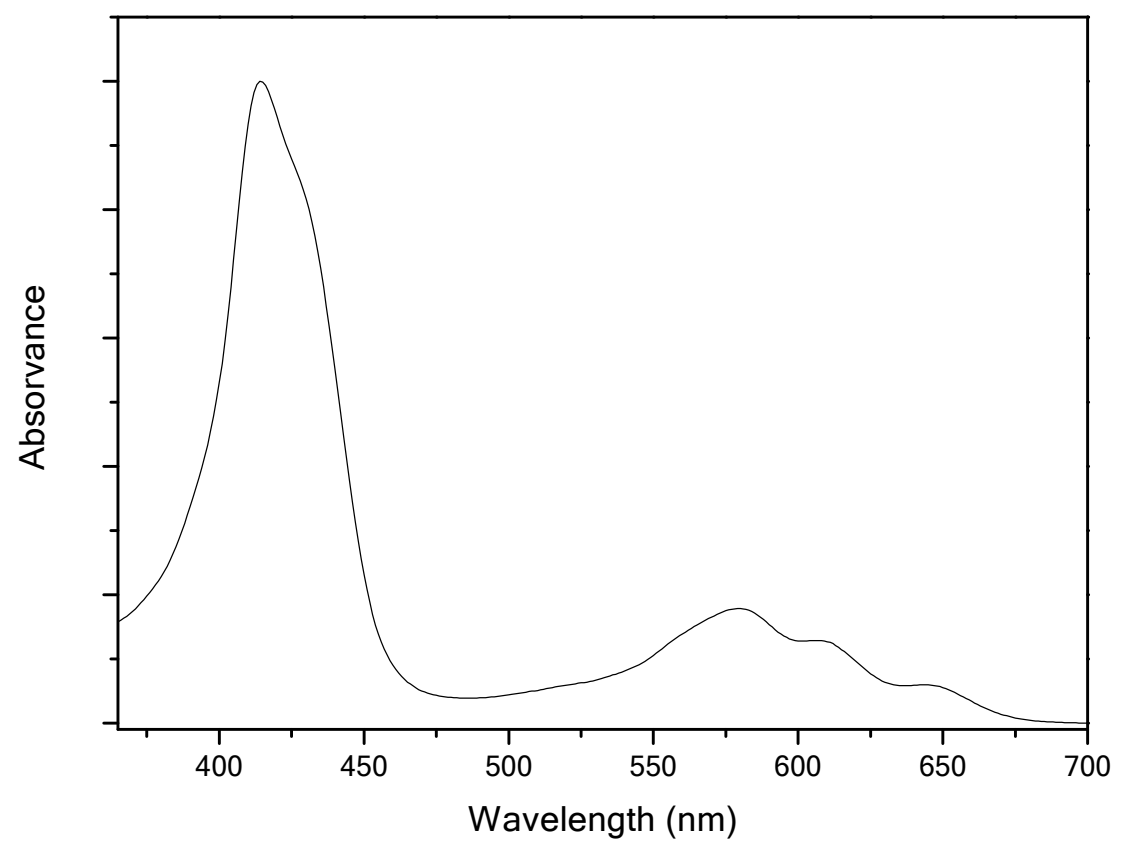

Figure S18. UV-Vis spectrum of corrole 8 (THF). 


\section{Copies of ${ }^{1} \mathrm{H}$ NMR and UV-Vis spectra of new porphyrins}

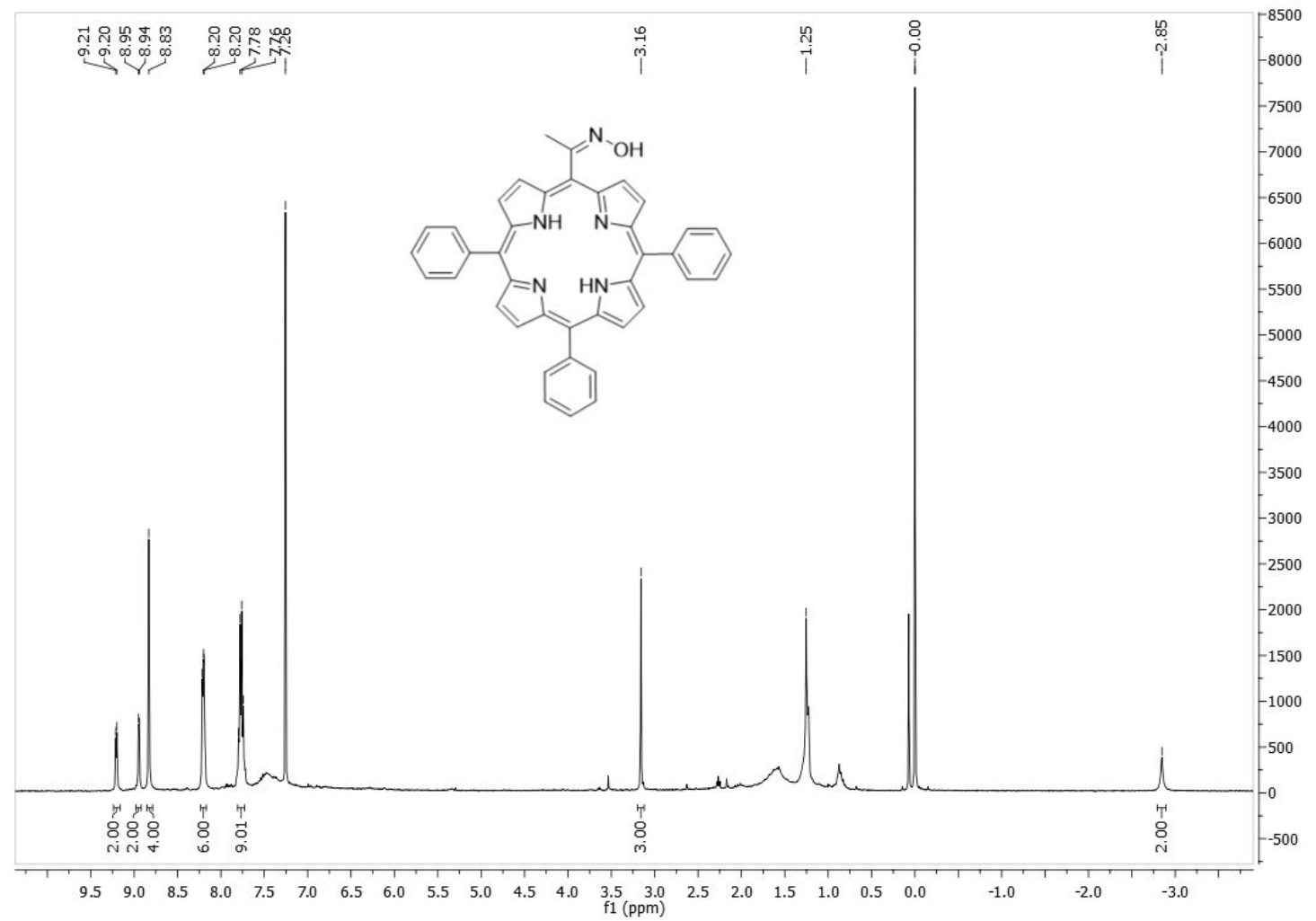

Figure S19. ${ }^{1} \mathrm{H}$ NMR spectrum of porphyrin 9a $\left(\mathrm{CDCl}_{3}\right)$.

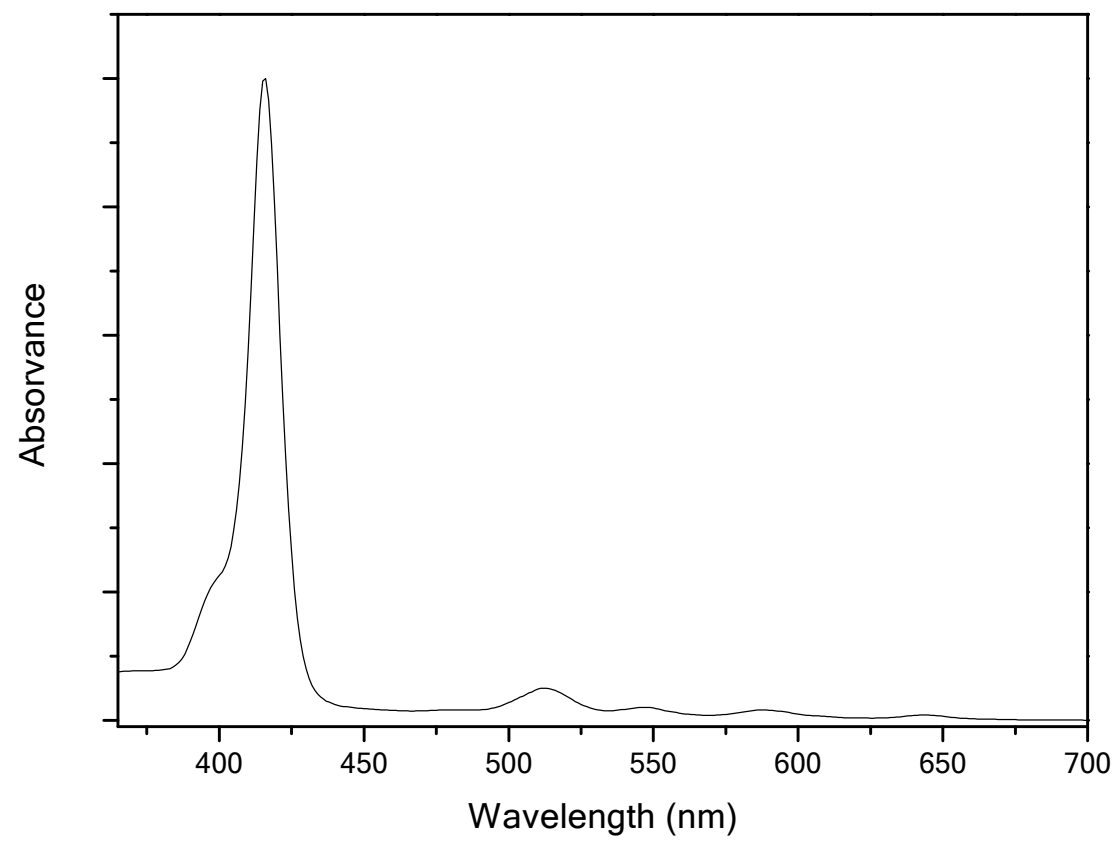

Figure S20. UV-Vis spectrum of porphyrin 9a $\left(\mathrm{CH}_{2} \mathrm{Cl}_{2}\right)$. 


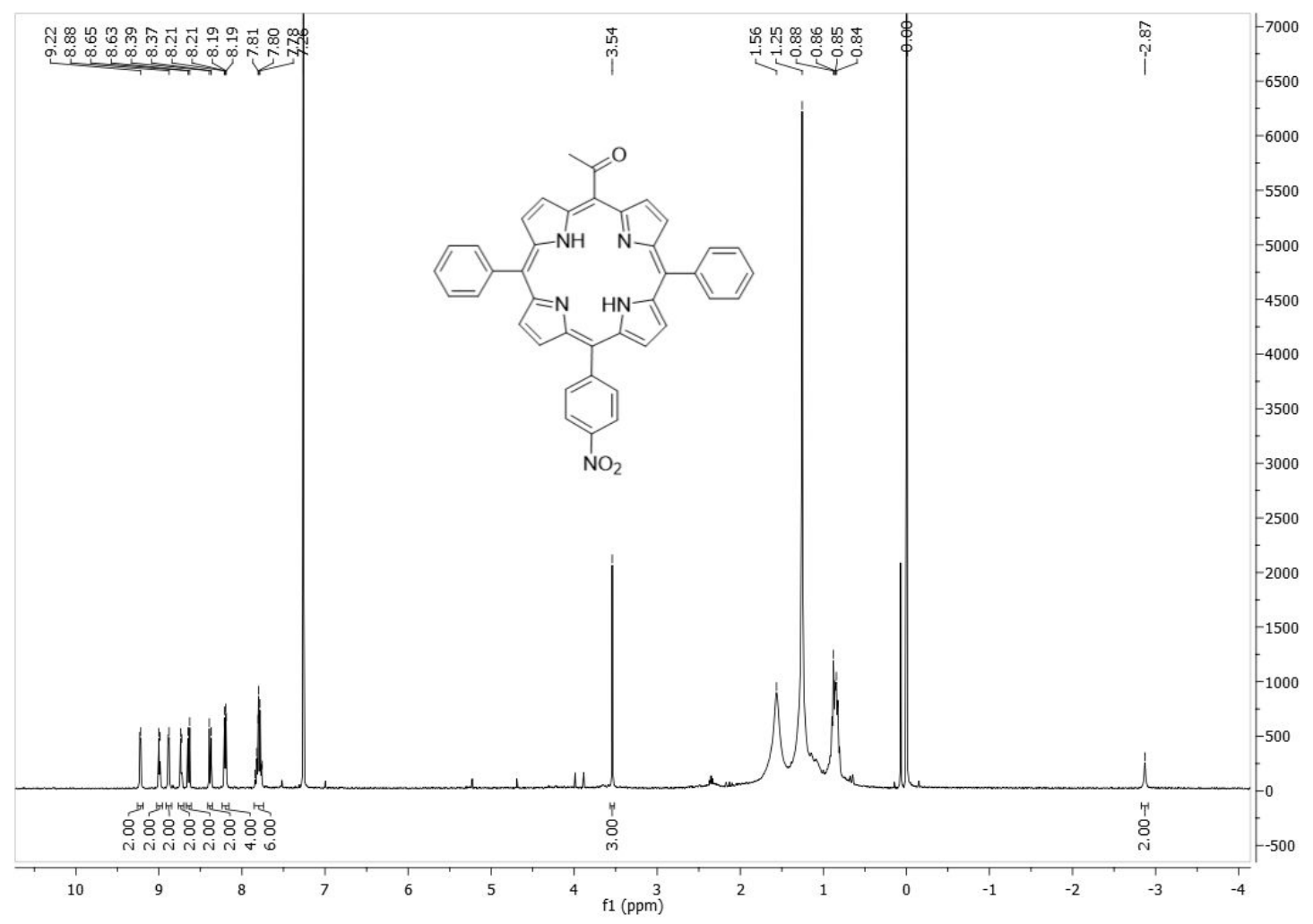

Figure S21. ${ }^{1} \mathrm{H}$ NMR spectrum of porphyrin $10\left(\mathrm{CDCl}_{3}\right)$.

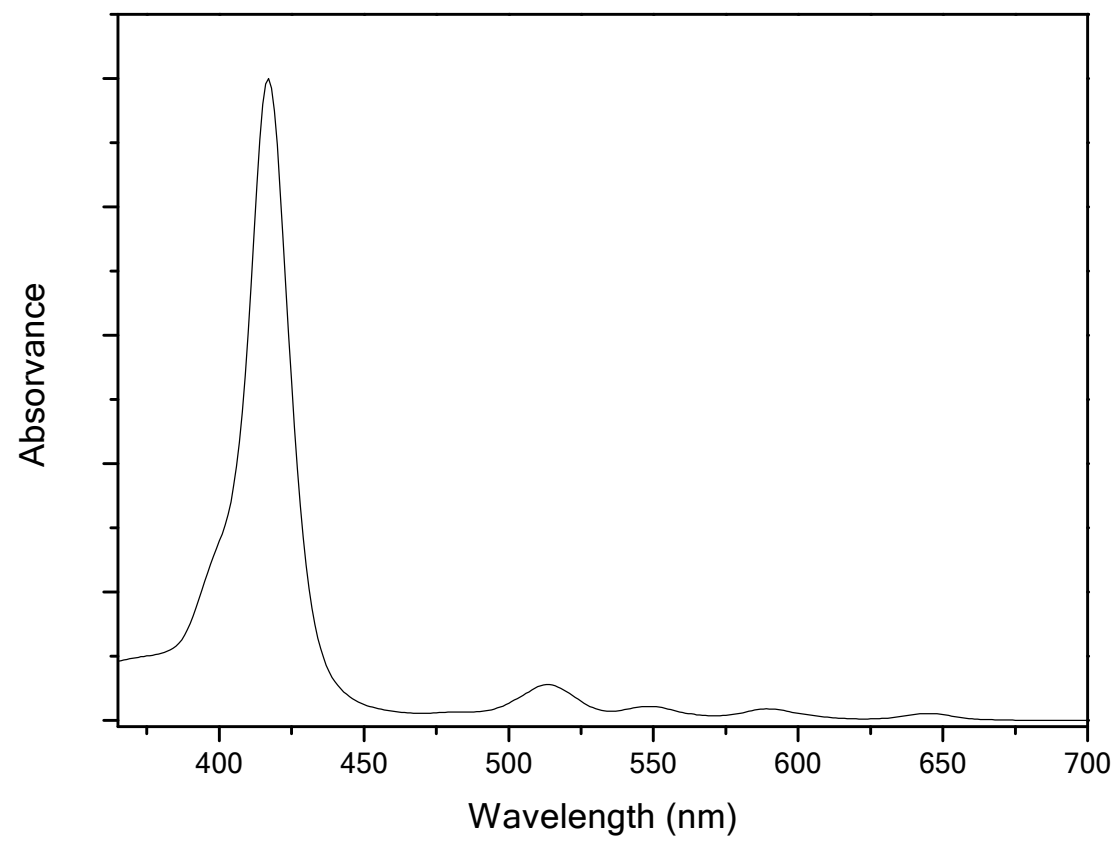

Figure S22. UV-Vis spectrum of porphyrin $10\left(\mathrm{CH}_{2} \mathrm{Cl}_{2}\right)$. 


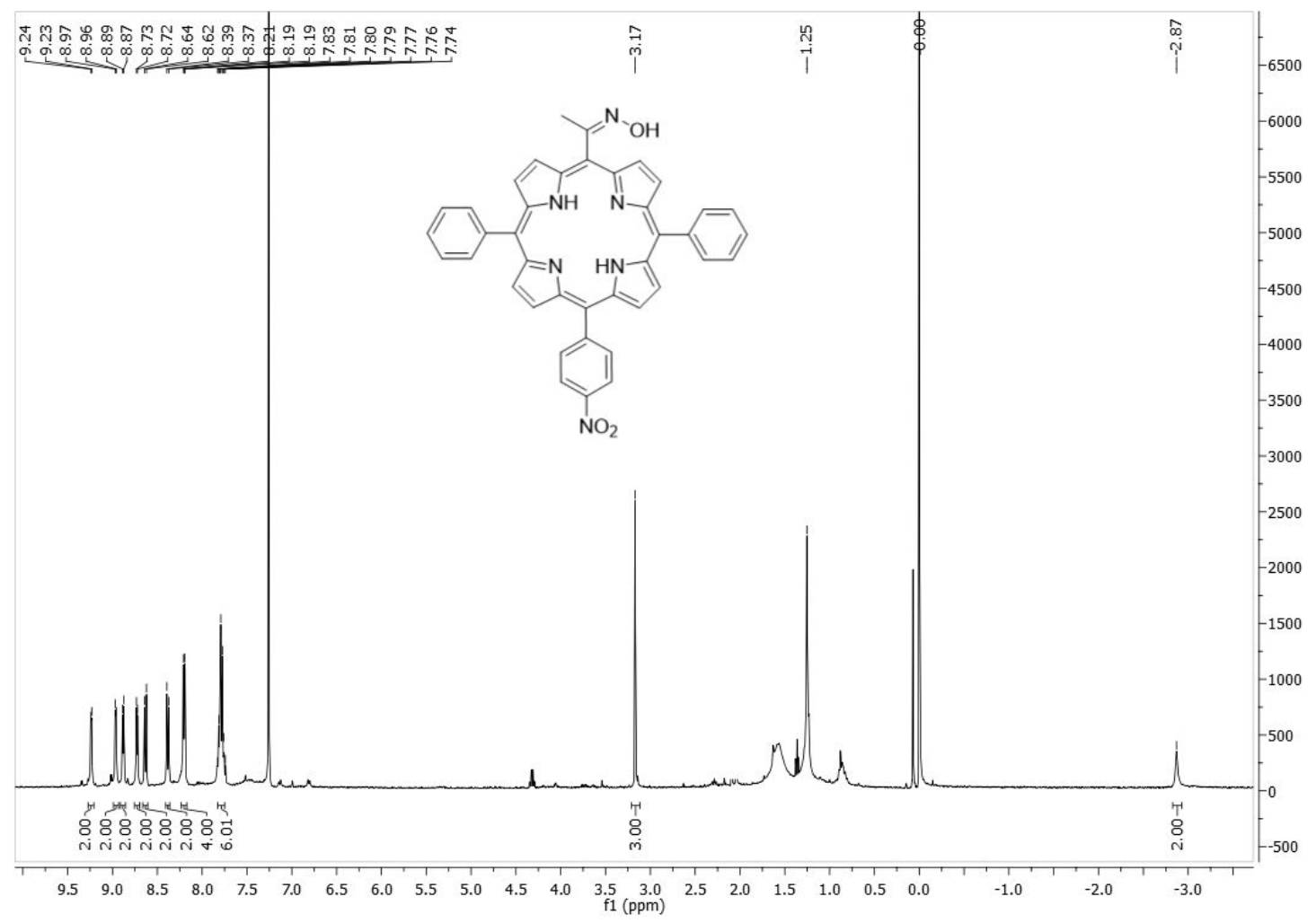

Figure S23. ${ }^{1} \mathrm{H}$ NMR spectrum of porphyrin $9 \mathbf{b}\left(\mathrm{CDCl}_{3}\right)$.

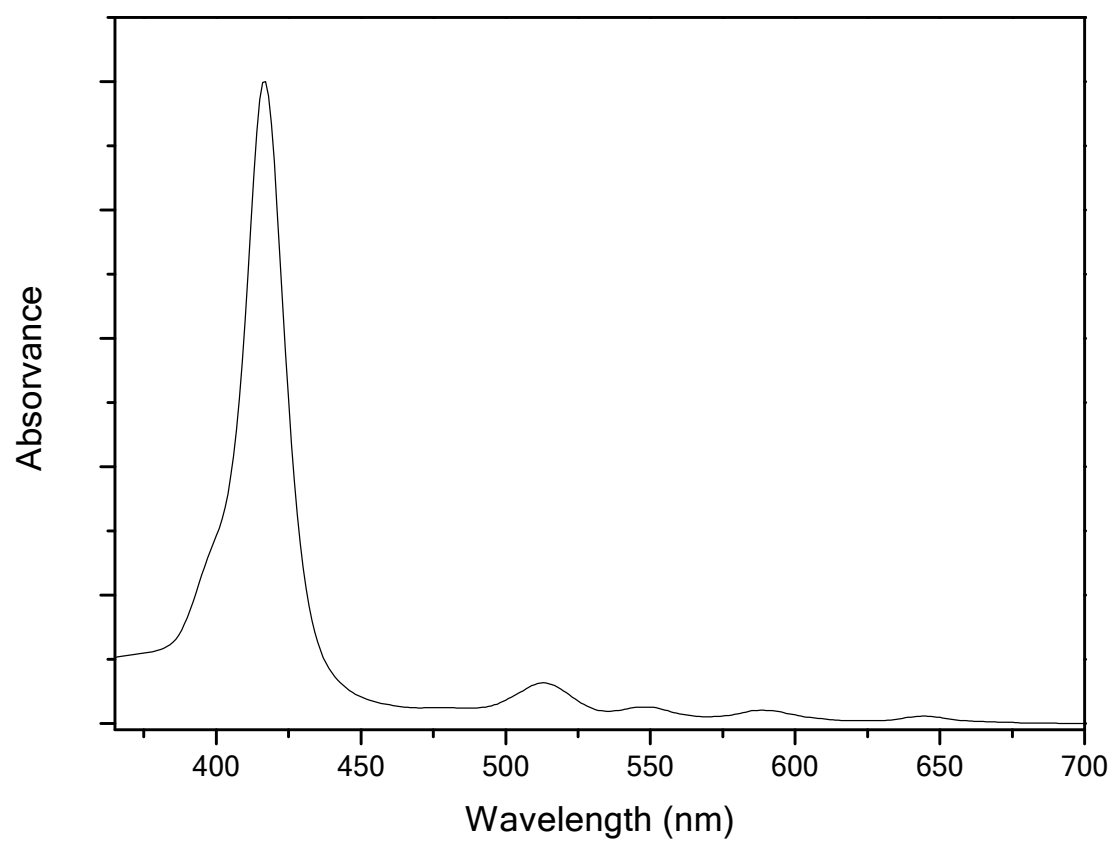

Figure S24. UV-Vis spectrum of porphyrin $9 \mathbf{b}\left(\mathrm{CH}_{2} \mathrm{Cl}_{2}\right)$. 


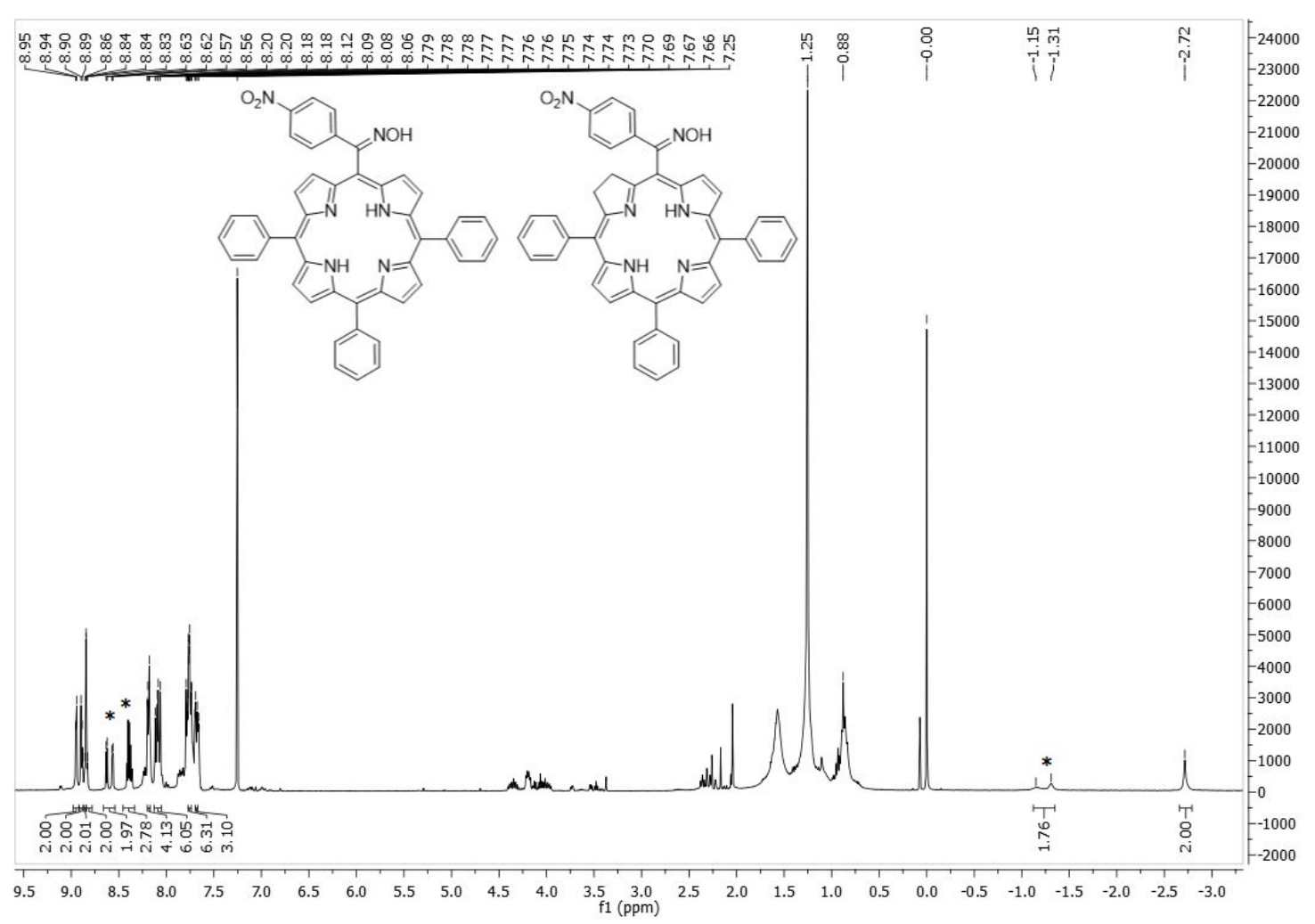

Figure S25. ${ }^{1} \mathrm{H}$ NMR spectrum of the porphyrin/chlorin 11a/12a mixture (57:43) $\left(\mathrm{CDCl}_{3}\right) . *$ Signals from the chlorin.

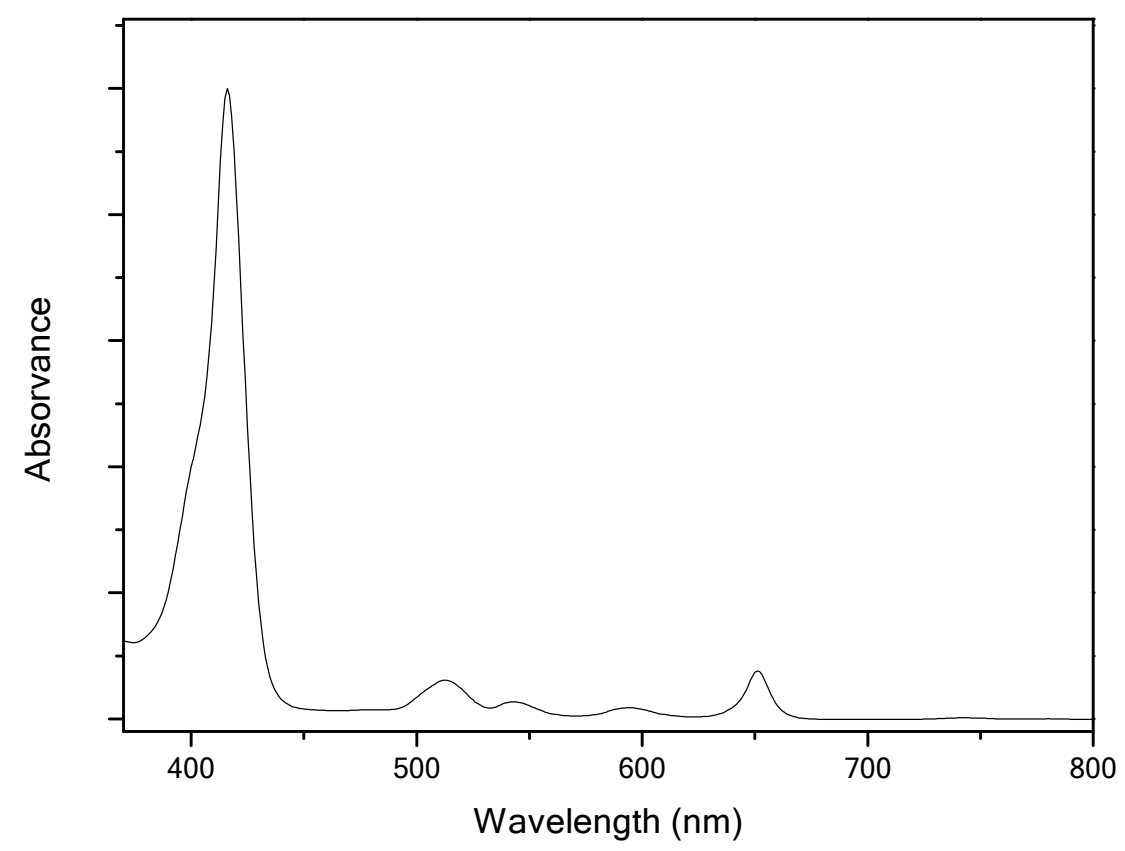

Figure S26. UV-Vis spectrum of the porphyrin/chlorin 11a/12a mixture (THF). 


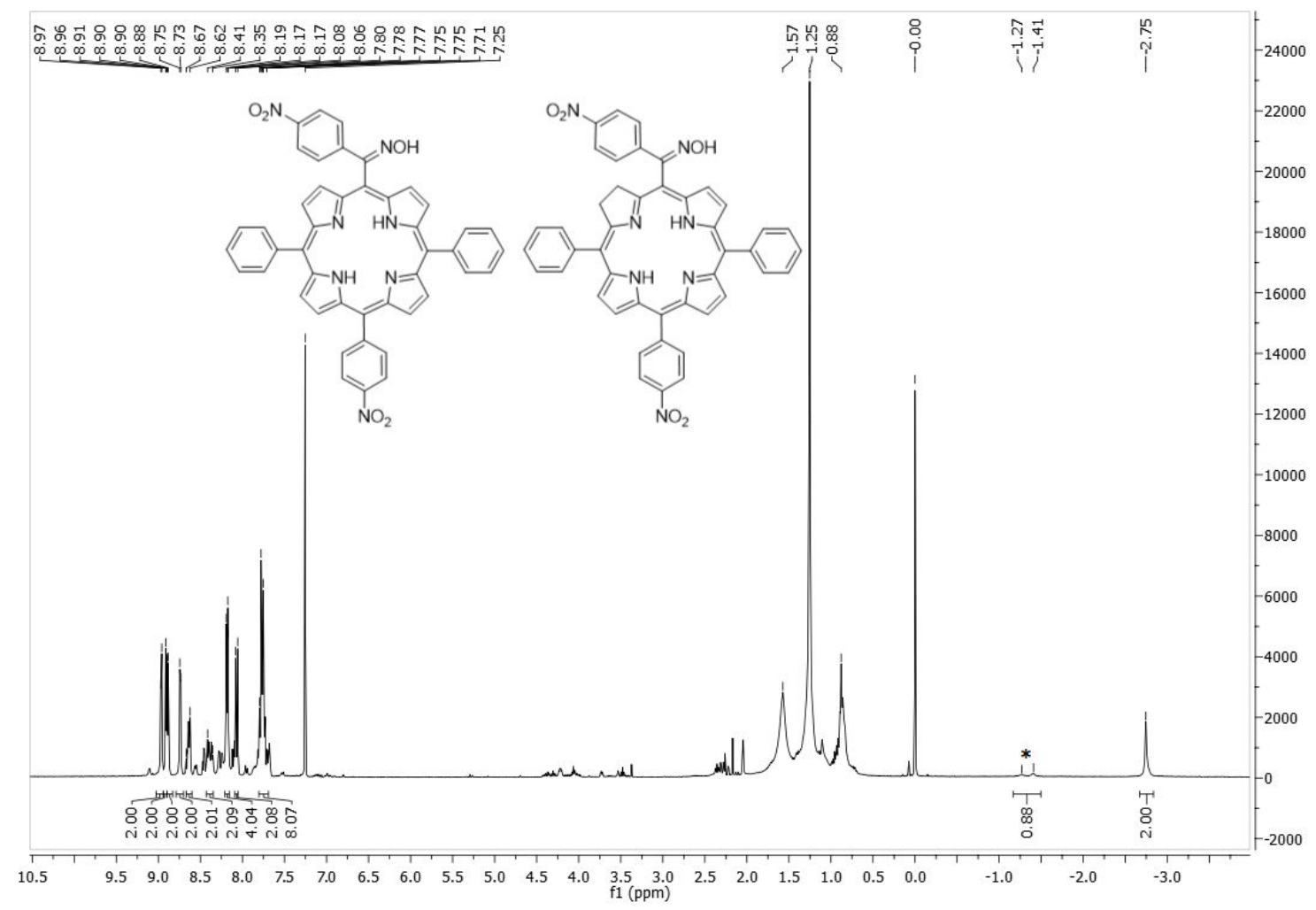

Figure S27. ${ }^{1} \mathrm{H}$ NMR spectrum of the porphyrin/chlorin 11b/12b mixture (76:24) $\left(\mathrm{CDCl}_{3}\right)$. *Signal from the chlorin.

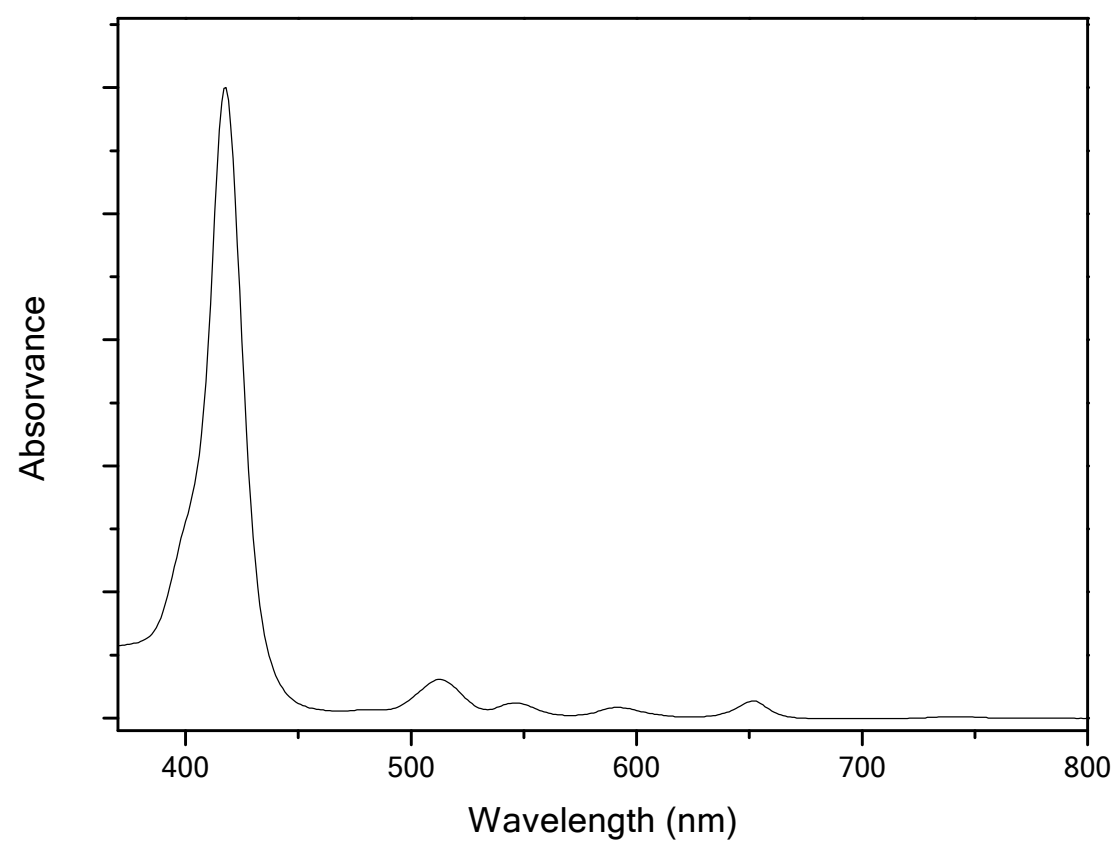

Figure S28. UV-Vis spectrum of the porphyrin/chlorin 11b/12b mixture (THF). 